\title{
KDM6A Gene
}

National Cancer Institute

\section{Source}

National Cancer Institute. KDM6A Gene. NCI Thesaurus. Code C96334.

This gene is involved in the modulation of histone methylation. 